\title{
Evaluation of distributed recharge in an upland semi-arid karst system: the West Bank Mountain Aquifer, Middle East
}

A G Hughes, M M Mansour \& N S Robins

British Geological Survey, Maclean Building, Wallingford, Oxfordshire OX10 8BB, United Kingdom (UK)

\begin{abstract}
Assessment of recharge in a structurally complex upland karst limestone aquifer situated in a semi-arid environment is difficult. Resort to surrogate indicators, such as measurement of spring outflow and borehole discharge, is a common alternative, and attempts to apply conventional soil moisture deficit analysis may not adequately account for the intermittent spate conditions that arise in such environments. A modelling approach has been made using the West Bank Mountain Aquifer system in the Middle East as a trial. The model uses object oriented software which allows various objects to be switched on and off. Each of the main recharge processes identified in the West Bank is incorporated. The model allows either conventional soil moisture deficit analysis calculations or wetting threshold calculations to be made as appropriate, and accommodates both direct recharge and secondary recharge.

Daily time steps enable recharge and runoff routing to be calculated for each node. Model runs have enabled a series of simulations for each of the three aquifer basins in the West Bank and for the whole of the West Bank. These provide recharge estimates
\end{abstract}


comparable to those prepared by earlier workers by conventional means. The model is adaptable and has been successfully used in other environments.

Keywords: carbonate rocks, groundwater recharge/water budget, karst, numerical modeling, West Bank

\section{INTRODUCTION}

There are numerous examples of upland limestone aquifers in semi-arid environments. These include the classic karst limestone lands of China, several examples around the Mediterranean Sea including the West Bank Mountain aquifer, Saudi Arabia, the dolomite aquifers in Gauteng, South Africa, the karst lands of South Australia and the United States. Lessons can be learnt from studies on lowland karst aquifers in semi-arid climates such as the Yucatan peninsular in Mexico and the limestone aquifers of Puerto Rico. The conjunction of karst with upland and semiarid climate is not uncommon, but understanding of the relevant recharge processes is incomplete, and the development of modelling techniques to replicate these processes is ongoing (Sanford 2002).

The key factors that control recharge in arid and semi-arid regions (e.g. Flint et al. 2002; Lewis \& Walker 2002; Wood et al 1997) are:

- high intensity rainfall, 
- accumulation of rainwater in depressions and streams,

- rapid percolation through cracks, fissures or solution channels.

Potential evapotranspiration almost always exceeds rainfall. Recharge may occur only in selected years, so that the concept of long term average (LTA) recharge may have little bearing on reality. Recharge is susceptible to near-surface conditions and is greatest where vegetation is sparse, soils are thin and permeable and where sporadic but high intensity rainfall occurs. Recharge is hampered where thick alluvial soils are present, as these may have a high retention storage for wet season rains, which may later be extracted by vegetation throughout the dry season.

Given an increasing understanding of the recharge processes in semi-arid upland karst areas, it is a logical next step to simulate these using numerical models. The now traditional soil moisture deficit (SMD) approach (Penman 1948) can be applied under most circumstances whereas wetting thresholds (Lange et al. 2003) are more appropriate under drier conditions (Hughes et al. 2006). Use of a distributed recharge model enables the various secondary recharge processes to be accounted for.

A regional scale distributed recharge model has been developed for the West Bank Mountain Aquifer system. This demonstrates the current modeling capability and provides recharge outputs that are compatible with those derived from existing empirical recharge estimates and output from regional scale groundwater flow models for the system. The model provides a platform for the assessment of distributed recharge in any upland aquifer system that receives both primary direct rainfall 
recharge and secondary transported recharge, with the added complication of secondary permeability derived from fractures and karstification.

\section{CURRENT UNDERSTANDING OF RECHARGE PROCESSES}

Lerner et al. (1990) and Simmers et al. (1997) describe the many potential recharge processes that can occur in semi-arid environment citing examples from the Negev, Israel and the limestone and dolostone provinces of the Middle East. It is normal for up to half the LTA rainfall to arrive at the water table as recharge at aquifer outcrop in a semi-arid environment (Table 1). Primary recharge occurs through direct rainfall recharge, whereas secondary processes include overland and stream flow losses through infiltration and to sink holes. Significantly, Bredenkamp et al. (1995) reported:

- contrary to the general assumption that estimation of groundwater recharge is more complex in a semi-arid region than in others, it appears that periods of prolonged drought interrupted by sufficient rain to provide recharge, can enhance the reliability of assessments of recharge;

- most groundwater analysts agree that the differences in recharge between wet and semi-arid environments stem mainly from the different recharge sources, and that the same techniques can be used to estimate recharge in all types of climate;

- vegetation is an important controlling factor, and the interaction between vegetation and recharge is critical to the assessment of the environmental impact, and to the determination of recharge. 
Bredenkamp et al. also observe that a great deal can be discerned from the behaviour of hydrological systems wherever groundwater discharge and, by implication groundwater recharge, are both reflected by stream low flows. Furthermore, cumulative rainfall departures from average rainfall conditions provide useful indicators of the range of hydrological responses that may occur in semi-arid regions.

De Vries and Simmers (2002) highlight the role of vegetation as a control on recharge and suggest that capillary rise and vapour transport of groundwater towards the root zone may result in fluxes towards the ground surface that affect recharge. They point out that a change in vegetation has a crucial influence on recharge in semi-arid areas, and that recharge increased significantly when the indigenous vegetation was removed in large parts of SE Australia over a hundred years ago.

Another key factor in semi-arid areas is the role of topographical depressions.

Scanlon et al. (1997) and Leduc et al. (1997) argue that most unsaturated flow in arid and semi-arid systems is focussed beneath topographic depressions. Herczeg et al. (1997) investigated chemical and isotopic indicators in a fractured carbonate sand aquifer in South Australia and find that point source features (such as dolines in a karst limestone) become active recharge centres after a threshold of sustained rain at $>2.5 \mathrm{~mm} \mathrm{~d}^{-1}$ has been maintained for 3 days. The concept of the wetting threshold was pursued by Lange et al. (2003) who show that, at least during high-magnitude rainfall, the steep rocky slopes in the West Bank and Israeli mountains are floodgenerating zones rather than areas of pronounced recharge into the underlying karst aquifer. Through experimentation they are able to determine the wetting thresholds 
required under certain topographical conditions to promote both runoff and infiltration.

\section{THE MOUNTAIN AQUIFER}

The anticlinal axis of the Mountain Aquifer system straddles the West Bank (PWA 2004). It creates an upland area comprising limestones with subordinate lithologies and there is a major Eocene sedimentary basin in the north-west. Direct rainfall recharge occurs to the permeable limestones in which secondary permeability and karstic flow are the dominant transport mechanisms. Secondary recharge may be routed via ephemeral influent wadi flow whilst spring discharge may be routed to wadis and sinks which return the flow to the groundwater system.

The limestone aquifer comprises four hydraulically distinct zones, the Shallow Aquifer, Upper Aquifer, Lower Aquifer and the Deep Aquifer. The traditional view of the Mountain Aquifer comprises three basins: the Western Aquifer, Eastern Aquifer and the North-Eastern Aquifer basins (Rofe and Raffety 1965). The piezometry and geological structure indicate a defined groundwater divide between the Western Aquifer and the Eastern Aquifer basins, and between the Western and North-Eastern Aquifer basins (Fig. 1). These divides run parallel to the surface water divides although there is a considerable offset of the groundwater divide to the west towards the crest of the anticline. The divide between the North-Eastern and the Eastern Aquifer basins is less certain, and although the Upper Aquifer is separated between the two, the Lower Aquifer may be in continuum. The North-Eastern Tip 
within the Eastern Aquifer Basin is hydraulically separated from the main basin by the deeply incised Wadi Fari'a, in which both the Upper and Lower aquifers crop out along the wadi flanks.

The Western Aquifer Basin outcrops and is recharged within the West Bank and flows west towards the Mediterranean to spring discharges in Israel. It is heavily exploited for abstraction with apportionment of resources between the West Bank and Israel managed by Israel. Considerable technical assistance has been provided to Palestine to understand the aquifer water balance in order to help to inform politicians for debate with their counterparts in Israel. The key to equitable apportionment is the determination of the volume of recharge received by the basin. However, there remain two issues which have yet to be resolved: one is the location of the eastern boundary of the basin, the no-flow divide between it and the Eastern Aquifer Basin; the other is an agreed and defensible estimate of overall infiltration to the Western Aquifer Basin.

Rofe and Raffety (1965) identified the axis of the main anticline, the Judean Anticline, as a dominant influence on groundwater flow directions. However, they assumed that groundwater flowpaths are primarily controlled by the dip of the more permeable strata. With a better understanding of the piezometric levels, it can be shown that the groundwater divide may not be coincident with the structural divide and is closer to the topographical divide, and in some areas, the exact location of the divide depends on local patterns of groundwater exploitation. 
In general, the topographic divide is to the east of the structural divide (Fig. 1), and hence an assumption that the divide is always aligned with the structural divide will tend to underestimate the recharge area of the Western Aquifer Basin and overestimate the recharge area of the Eastern Aquifer basin. The boundaries of the North Eastern Basin, as mapped by Rofe and Raffety (1965), are particularly at odds with surface water flow directions, and hard to justify on hydraulic grounds.

\section{Early recharge estimates}

An empirical relationship between recharge and rainfall was developed by Goldschmidt (1955), based on the water balance method. This assumed that $360 \mathrm{~mm}$ of the average annual rainfall is required to overcome evaporative processes, and equated long term average recharge to the aquifer as $90 \%$ of the long term average rainfall minus $360 \mathrm{~mm}$. Allowing $4 \%$ further loss to storm runoff a value of $317 \mathrm{Mm}^{3}$ $\mathrm{a}^{-1}(\mathrm{M}=$ million, $\mathrm{a}=$ annum $)$ can be derived over the areal extent of the aquifer outcrop (excluding aquiclude outcrop and using an arbitrary aquifer boundary to the east). Goldschmidt \& Jacobs (1958) argued that almost the entire discharge from the aquifer was accounted for in the Yarqon and Nahal Taninim springs situated in Northern Israel on the Mediterranean coast and equated their yield to the total recharge available to the aquifer. This approach provided a value for recharge of 326 $\mathrm{Mm}^{3} \mathrm{a}^{-1}$ for an average year. Estimates were revised whilst abstraction was increased at the expense of spring discharge. Assaf et al. (1993) estimated a safe yield for the Western Aquifer Basin of $350 \mathrm{Mm}^{3} \mathrm{a}^{-1}$ of which $40 \mathrm{Mm}^{3} \mathrm{a}^{-1}$ flowed from the Taninim spring, with an elevated $\mathrm{Cl}$ concentration of $>400 \mathrm{mg}^{-1}$. This was a later revised upwards to $399 \mathrm{Mm}^{3} \mathrm{a}^{-1}$ (MNIWC 1999). 
The empirical approach of Goldsmidt and Jacobs (1958) was applied to the Eastern Basin by Guttman \& Zuckerman (1995) who improved the empirical relationship between rainfall and recharge by applying a variety of rainfall values, and Ba'ba'(1996) who used spring flow records to update the empirical relationships. Other recharge estimates have been produced from groundwater models including work by Bachmat (1995) for the Western Aquifer Basin and Guttman and Zukerman (1995) for the Eastern Aquifer Basin.

The empirical estimates defy the complexity of the partly karst, fractured aquifer. It also ignores the spate and drought nature of a semi-arid climate. The range of results so derived has not helped the process of amicable apportionment and average values have had to be adopted, as for example, in the negotiations resulting from the Oslo accords.

None of these approaches considered the recharge processes actually at the outcrop of the aquifer. The reasons for this were twofold: 1) the complex structural setting of the Mountain Aquifer did not lend itself to conventional investigation and analysis, and 2) the recharge processes could not be defined by any one analytical system, for example, soil moisture deficit analysis (Penman 1948), then in use. Nevertheless, a consistent recharge estimate was reached for the Western Aquifer Basin of around $350 \mathrm{Mm}^{3} \mathrm{a}^{-1}$ (Table 2), a value since confirmed by SUSMAQ (Sustainable Management of the West Bank and Gaza Aquifers project, unpublished data, 2003). Recharge estimates for the Eastern Aquifer Basin attain a consistent value of 130 $\mathrm{Mm}^{3} \mathrm{a}^{-1}$, whilst few estimates are available for the North-Eastern Basin. Additionally, 
a small number of studies present estimates for the whole of the West Bank. These arrive at a consistent value of just over $800 \mathrm{Mm}^{3} \mathrm{a}^{-1}$, i.e. more than $200 \mathrm{Mm}^{3} \mathrm{a}^{-1}$ greater than the sum of the estimates for each individual basin. Guttman (1998) used data for the period 1969 to 1994 to provide a minimum estimate of recharge to the West Bank of $60 \mathrm{Mm}^{3} \mathrm{a}^{-1}$ for a dry year and $460 \mathrm{Mm}^{3} \mathrm{a}^{-1}$ for a wet year.

With the exception of Rofe and Raffety (1965), who used the Penman (1948) soil moisture approach, all the work in the West Bank has been directed towards producing empirical formulae that describe the relationship between rainfall and recharge. This approach, whilst often based on detailed hydrogeological studies, does not allow the identification of individual components of recharge processes such as indirect recharge to wadis or any predictive work to determine the impact of land use changes on recharge. To address this deficiency a process-based distributed recharge model has been developed and applied to the three basins in the West Bank. A larger scale pilot study model was also developed for a small catchment in the Western Aquifer basin (Hughes et al. 2006)

\section{DISTRIBUTED RECHARGE MODEL}

De Vries and Simmers (2002) advocate a distributed recharge water-balance approach, with full account of spatial variability using short time steps. This has been pursued using object oriented code from the ZOOM suite of software (Spink et al. 2003; Spink et al. 2006) using available piezometric and flow data to refine the model. 
Object-oriented $(\mathrm{OO})$ techniques are widely used in commercial computer software. The British Geological Survey in conjunction with the University of Birmingham, UK and the UK Environment Agency have been developing and applying OO groundwater models. The current suite of models includes a groundwater flow model, ZOOMQ3D (e.g. Jackson et al. 2005), an advective particle tracking model, ZOOPT (e.g. Stuart et al. 2006) and a distributed recharge model, ZOODRM (e.g. Hughes et al. 2006). The development of this suite of groundwater models has demonstrated the advantages of $\mathrm{OO}$ techniques for including advanced numerical techniques such as local grid refinement as well the flexibility to switch on and off various mechanisms (Spink et al. 2003).

The distributed recharge model requires that recharge is calculated at the appropriate points over the study area. A daily time step is used for the recharge calculation, with the output supplied as monthly averages. Separate objects (Fig. 2) are used to represent separate entities such as soil, wadi, grid and node. The recharge calculation is undertaken within a node object. These node objects are held, in turn, within grid objects and grids can be nested to increase resolution in discrete areas. This facility was developed to provide input data in the correct form for the groundwater flow model ZOOMQ3D, which incorporates local grid refinement in a Cartesian mesh (Spink et al. 2006).

The recharge model is thus able to represent all the many and diverse flow processes which describe the onward transport of rainfall arriving at the aquifer outcrop in any complex system (Fig. 3). These are the surface flow processes and water percolation, 
the groundwater flow to shallow spring systems and the delay time required by the percolating water to leave the unsaturated zone and become part of the water table. The surface water movement to wadi floors is based on the local topographical and geological characteristics. Surface water movement and the resulting recharge are based on the application of either the soil moisture deficit recharge method (Penman 1948) or the wetting threshold recharge method (Lange 2003). Six numerical runs were undertaken to investigate the effect of changing the values of the parameters on the recharge values.

The data needs and analysis within the model fall into five categories:

1. distributed daily rainfall and distributed monthly potential evaporation

2. landuse and associated values and slope aspect

3. wadi flow and spring flow

4. urban areas

5. irrigated areas

A $400 \mathrm{~m}$ square cell size was adopted as a compromise between representation and model run time. Distributed rainfall data were provided on a daily basis for the years 1990 to 1997 (Kilsby et al. 2005). Potential evaporation is available as monthly data from six meteorological sites whilst model input also includes the spatial distribution of the LTA data in order to smooth the interpolation between the meteorological stations.

The landuse type specified at any recharge node controls the values of the root constant (C) and the wilting point (D) if the soil moisture deficit recharge calculation 
type is to be applied, or the values of the wetting threshold if this calculation is preferred. Two different sets of runs have been carried out, the first based on the soil moisture deficit method where $\mathrm{C}$ and $\mathrm{D}$ values are set according to the landuse types (Table 3). The second set of runs is based on the application of the wetting threshold method where the wetting threshold values are constant throughout the area modelled.

The north-west part of the West Bank is characterised by a sub-humid climate with the potential of significant recharge occurring during the wet season even though there may be thick soil cover. Both the soil moisture deficit method and the wetting threshold method may apply in this area. The south-east part of the West Bank is more arid with a lower recharge potential. It is more likely that the wetting threshold method is applicable in this area than the soil moisture deficit method.

The digital terrain map (DTM) was reduced to a slope aspect map in order to determine surface drainage directions. The scale of the model led to a loss in the accuracy of the DTM data and small areas were identified with nodes that were not connected to wadi nodes. The recharge model assumes that if the routed runoff water does not reach a wadi node it will go to a virtual pond. As this is not what happens in reality some manual modification of the aspect map was required to connect these virtual ponds to the nearest wadis. The aspect direction at any node controls the direction of movement for surface water transport, generated as a proportion of both the rainfall plus any water received from an adjacent node, towards any one of its four adjacent nodes. Although the runoff routing process is simple, it is adequate for a time step of only one day. The runoff coefficient values for the karst limestone aquifer units were set at 0.3 , whilst for the Yatta Formation, which forms the aquitard 
between the Upper and Lower Aquifers, it was set at 0.5, and for the outcrop areas of the impermeable Senonian marls and cherts it was set at 0.9. The amount of overland loss between nodes is set to a constant value of $0.0005 \mathrm{~m}^{-1}$.

Wadi flow is calculated at each wadi node at the end of each daily time step, and the flows collected at the wadi nodes are cumulated in the downstream direction. Water losses are assumed to occur during this process throughout the length of the wadi beds, and $1 \%$ of the total daily flow calculated at a stream node is assumed to infiltrate directly to the unsaturated zone.

In the nine major urban areas in the West Bank losses from water mains and sewers are assumed to be $30 \%$ and $20 \%$ of the total water in supply respectively (McKenzie, British Geological Survey, unpublished data, 2001). The urban recharge nodes include two recharge processes. The first represents the direct infiltration of water from water mains and sewers, and the second represents the recharge generated from rainfall that obeys the SMD recharge calculation method for open areas that represent about $20 \%$ of the total urban field. All the urban nodes are connected to one specified stream node, used to represent a wadi, or in reality a storm water sewer, discharging at a specified wadi.

There are five cultivated and irrigated areas. The amount of irrigation water applied in these areas ranges from 5.8 to $34.8 \mathrm{Mm}^{3} \mathrm{a}^{-1}$ but the transmission losses are maintained at a constant $15 \%$ and the field losses at $25 \%$. It is assumed that irrigation water is applied uniformly across each area, and that the dry season extends over seven months from April to October. The yearly irrigation water has been distributed across 
the remaining months. The root constant $\mathrm{C}$, the wilting point $\mathrm{D}$ and the empirical factor that determines the amount of water lost from the ground when the SMD level falls between the $\mathrm{C}$ and $\mathrm{D}$ values are set to appropriate values for the crops grown in the irrigated areas.

In addition, although not used in the regional scale model of the West Bank, there is a tool that assigns spring discharge. If it is assumed that part of the recharge flow that reaches an unsaturated node connected to a spring moves horizontally and discharges to a wadi via the spring, then springs can be represented as objects that are connected to the unsaturated node objects. This also assumes that there is a direct head gradient towards the spring from the unsaturated node objects and that these nodes lie within a specified radius of the spring.

Various runs were carried out for the recharge model as follows:

- Wetting threshold (WT) method with a WT of 20, 30 and $40 \mathrm{~mm}$

- Soil Moisture Deficit (SMD) method using C and D values distributed according to landuse

- Urban areas included for both methods; for a WT of $30 \mathrm{~mm}$ and SMD

- Irrigated area included for both methods; for a WT of $30 \mathrm{~mm}$ and SMD

In all, a series of nine simulations of the recharge model were undertaken. Three runs examined the impact of varying the wetting threshold; WT $=20,30$ and $40 \mathrm{~mm}$, together with a single SMD run. For the base case wetting threshold (WT $=30 \mathrm{~mm}$ ) and the SMD run, two further sets of runs were undertaken with urban recharge processes and losses from irrigated fields activated (Fig. 4a and Fig. 4b). Finally one 
run was undertaken to examine the impacts of smoothing the Potential Evaporation (PE) data.

It was found that the WT recharge calculation method, with WT values of 20, 30, or $40 \mathrm{~mm}$, yields higher rates of recharge than the SMD recharge method (Table 4). The increase of the amount of recharge caused by reducing the WT value from $40 \mathrm{~mm}$ to $20 \mathrm{~mm}$ is in the order of $17 \%$ while the difference in the result produced by using WT of $20 \mathrm{~mm}$ and the one produced by the SMD method is approximately $64 \%$. The large difference in the LTA recharge values between the WT and SMD method is caused by the larger soil store that needs to be satisfied in the SMD method before recharge can occur.

The model outputs were summarised in three ways: total and basinal recharge estimates for each of the Western, Eastern and North-Eastern Aquifer basins (Table 5), spatial distribution of long-term average recharge (e.g. Fig. 4a) and annual summaries of surface water flows. These outputs were then compared with the historical data to identify the run parameters that produced the best fit. The long-term average recharge calculated by the recharge model for the Western Aquifer Basin for the period January 1990 to December 1996 varies between 0.74 $\mathrm{Mm}^{3} \mathrm{~d}^{-1}\left(269 \mathrm{Mm}^{3} \mathrm{a}^{-1}\right)$ for the SMD approach and $1.25 \mathrm{Mm}^{3} \mathrm{~d}^{-1}\left(455 \mathrm{Mm}^{3} \mathrm{a}^{-1}\right)$ for the wetting threshold method, with $\mathrm{WT}=20 \mathrm{~mm}$. The most likely long-term average recharge value lies between these two extremes, i.e. a wetting threshold value of 30 $\mathrm{mm}$ and accounting for urban recharge processes and irrigation losses results in recharge of $1.18 \mathrm{Mm}^{3} \mathrm{~d}^{-1}\left(430 \mathrm{Mm}^{3} \mathrm{a}^{-1}\right)$ to the Western Aquifer Basin (Figs 4a and 
$4 b)$. These estimates compare well with earlier work which derived long-term average recharge values for the Western Aquifer Basin of between 317.5 and $360 \mathrm{Mm}^{3} \mathrm{a}^{-1}$.

Studying the maps of long-term average recharge shows a common pattern for the results of each simulation (Figs $4 a-4 c$ ). The highest recharge occurs in the northwest of the West Bank and the lowest in the south-east. This corresponds to the spatial distribution of the rainfall. Other features which influence the distribution of recharge include the wadis, which result in lines of enhanced recharge along the wadi beds, urban areas and irrigated areas which create "patches" of increased recharge.

An additional composite run was prepared using a distributed mixture of soil moisture deficit and wetting threshold methods (results shown in Fig. 4c). The initial results of the composite run indicate that $45 \%$ of the overall recharge in the West Bank takes place in the Western Aquifer Basin, i.e. that the Western and the North- Eastern Basins are wetter than the Eastern Basin, with recharge reducing eastwards and southwards, reflecting the rainfall distribution over the West Bank. The SMD calculation method is, therefore, most likely to be applicable in the wetter north and west while the WT calculation method is most likely to be more suitable for recharge calculation in the drier south and east. The boundary between the applicability of the two methods is set at the $500 \mathrm{~mm}$ LTA rainfall contour (Lerner et al., 1990). The long-term average distributed recharge (Fig. 4c) shows that recharge is $110 \mathrm{~mm} \mathrm{a}^{-1}$ where rainfall is greater than $500 \mathrm{~mm} \mathrm{a}^{-1}$. The application of the wetting threshold method over the whole model area yields a LTA recharge value of $150 \mathrm{~mm} \mathrm{a}^{-1}(0.41$ $\mathrm{mm} \mathrm{d}^{-1}$ ) while the application of the SMD method yields a recharge value of $105 \mathrm{~mm}$ 
$\mathrm{a}^{-1}\left(0.29 \mathrm{~mm} \mathrm{~d}^{-1}\right)$. The composite model results in a LTA recharge value of $144 \mathrm{~mm} \mathrm{a}^{-}$ ${ }^{1}\left(0.39 \mathrm{~mm} \mathrm{~d}^{-1}\right)$.

Comparison of the model output with measured surface water flows has been undertaken to provide further validation of the recharge model. Annual totals of wadi flows for each of the years the model has been run have been compared with measured flows (Fig. 5). This has been undertaken for four wadi gauging stations whose flows are reported in the Hydrological Yearbook of Israel (e.g. Hydrological Service of Israel, 2003). These wadi gauging stations are close to the boundary of the outcrop area of the Western Aquifer Basin. Generally, the modelled results show reasonable agreement with the measured flows. The best simulated year is 1992/3 where both the WT and the SMD method reproduce both the magnitude and pattern of measured flows. The poorest match is for 1990/1 where the modelled results overestimate the measured flows.

\section{CONCLUSIONS}

Recharge processes in upland karst limestone aquifers are many and diverse. It is, therefore, tempting not to attempt to calculate recharge but to monitor surrogate indicators of recharge and develop empirical relationships which can be calibrated against data such as spring discharge and abstraction.

The complex Mountain Aquifer system of the West Bank is one such aquifer system. Divided into an Upper and a Lower aquifer it is split into three basins, the Western and Eastern Aquifer basins which straddle the core of the anticline forming the 
mountains and the Eocene sedimentary basin which forms the North Eastern Basin. Good control is available for recharge estimates in the Western Aquifer basin as much of the discharge is focussed on a single spring for which flow data are available. None of the existing recharge estimates for the three basins actually considered the recharge processes and attempted to quantify them.

A distributed object oriented recharge model has now been deployed to evaluate all the recharge processes that have been observed at work in the Mountain Aquifer. Despite the coarse scale of the model, the results derived using either a traditional soil moisture deficit approach or a wetting threshold approach, or a combination of both, are comparable with earlier estimates. Whilst this is the case, and simpler methods may appear to negate the use of the more complex, distributed method, there are a number of advantages in using more complex methods. These include the defensible nature of the estimate which is derived from calculated inputs to the system, the results of the recharge estimate are distributed over time and space and the complexity of the method can be increased as understanding increases. The distributed recharge method can also be used to provide predictions, for example for climate change scenarios.

The object oriented code allows a range of processes to be switched on or off. The West Bank model incorporated effective rainfall, soil moisture deficit or wetting threshold calculations for recharge and runoff, direction and amount of overland flow, wadi flow, and the effects of both urban and irrigated areas. The code can, therefore, easily be adapted for application in any complex environment either by switching off codes used in the West Bank model that may not apply to a given area, or by 
switching on additional process that may apply (Table 6). The code, therefore, has a universal application which has already proved valuable in a number of different climatic and geological settings.

Acknowledgement: The work was undertaken within the Sustainable Management of the West Bank and Gaza Aquifers Project which was funded by the UK Department for International Development. The project partners included the University of Newcastle and the Overseas Development Institute working alongside the Palestinian Water Authority (PWA), for whom a major outcome was training and capacity building. The development of the recharge model was undertaken by the British Geological Survey supported by the PWA for data acquisition. The paper is published by permission of the Director, British Geological Survey (Natural Environment Research Council). 


\section{REFERENCES}

Assaf K, Khatib N, Kally E, Shuval H (1993) A proposal for the development of a regional water master plan. Israel/Palestine Center for Research and Information, Jerusalem

Ba'ba' M M (1966) Hydrogeological investigations in the Eastern Basin of the West Bank. MSc Thesis, Institute of Hydraulic Engineering, Delft

Bachmat Y (1995) Hydrologic model of the western mountain groundwater basin for Stage 1, Harvard Middle East Water project. Technical report Institute for Social and Economic Policy in the Middle East, Harvard University, US.

Bredenkamp D B, Botha L J, van Tonder G J, van Rensburg H J (1995) Manual on estimation of groundwater recharge and aquifer storativity. Report Water Research Commission, Pretoria TT 73/95

CDM (1998) Study of the sustainable yield of the Eastern Aquifer Basin: final report. Camp Dresser McKee/Morganti Report for Palestinian Water Authority and US Agency for International Development

Flint A L, Flint L E, Kwicklis E M, Fabryka-Martin J T, Bodvarsson G S (2002)

Estimating recharge at Yucca Mountain, Nevada, USA: comparison of methods. Hydrogeology Journal 10 (1): 180-204. 
Goldschmidt M J (1955) Precipitation and runoff from Jordan and Litani catchments. Hydrological Paper 1, Hydrological Service of Israel, Jerusalem

Goldschmidt M J, Jacobs M (1958) Precipitation and replenishment of the Yarqon and Nahal Hatteninim underground catchments. Hydrological Paper 3, Hydrological Service of Israel, Jerusalem

Guttman Y (1995) The hydrogeology of the Eastern Basin and possibilities for the development of water resources from the Pharaoh Stream to the Judean Desert. Report TAHAL Consulting Engineers 01/95/105.

Guttman Y (1998) Annual Report - 1997: Sub Project B: Hydrogeology of the eastern Aquifer in the Judea Hills and Jordan Valley. Report TAHAL Consulting Project 02WT9719, for German-Israeli-Jordanian-Palestinian Joint Research Program for the Sustainable Utilization of Aquifer Systems

Guttman Y and Zuckerman Ch (1995) Flow model in the Eastern Basin of the Mountains of Judea and Samaria from the Pharoah Stream to the Judean Desert. Report TAHAL Consulting Engineers 01/95/66.

Herczeg A L, Leaney F W J, Stadter M F, Allan G L, Fifield L K (1997) Chemical and isotopic indicators of point-source recharge to a karstic aquifer, South Australia. Journal of Hydrology 192 (1-4): 271-299 
Hoetzl H 1995. Groundwater recharge in an arid karst area (Saudi Arabia). IAHS Publication 232: 195-207

Hughes AG, Mansour M M, Robins N S, Peach D W (2006) Numerical modeling of runoff recharge in a catchment in the West Bank. In: MODFLOW and More:

Managing Ground-Water Systems - Conference Proceedings, Colorado School of Mines, May 2006, Volume 1: 385-389

Hydrological Service of Israel (2003), Hydrological Yearbook of Israel 1999/2000, Jerusalem, Israel, ISSN 0073-4217.

Jackson CR, Hughes AG, Ó Dochartaigh BE, Robins NS and Peach DW (2005).

Numerical testing of conceptual models of groundwater flow: A case study using the Dumfries Basin Aquifer, Scottish Journal of Geology, vol. 41 (1), pp 51-60.

Kilsby C G, Burton A, Moaven-Hashemi A, Tasin A, O’Connell P E (2005)

Stochastic space-time modelling of West Bank rainfall for present and future climates. Report 42, SUSMAQ, Palestinian Water Authority, University of Newcastle

Lange J, Greenbaum N, Husary S, Ghanem M, Leibundgut C, Schick A P (2003)

Runoff generation from successive simulated rainfalls on a rocky, semi-arid, Mediterranean hillslope. Hydrological Processes 17, 279-296 
Leduc C, Bromley J, Schroeter P (1997) Water table fluctuation and recharge in semiarid climate: some results of the HAPEX-Sahel hydrodynamic survey (Niger). Journal of Hydrology, 1997, 189 (1-4): 123-138

Lerner D N, Issar A S, Simmers I (1990) Groundwater recharge: a guide to understanding and estimating natural recharge. International Association of Hydrogeologists, International Contributions to Hydrogeology 8

Lewis M F, Walker G R (2002) Assessing the potential for significant and episodic recharge in southwestern Australia using rainfall data. Hydrogeology Journal, 10 (1): $229-237$

MNIWC (1999) Development of utilization and status of water resources in Israel until Fall 1998. Ministry of Natural Infrastructures Water Commission Hydrological Service, Jerusalem

Penman H L (1948) Natural evaporation from open water, bare soil and grass, Proceedings of the Royal Society London, Series A, 193: 120-145

PWA (2004) Hydrogeological Map of the West Bank, 1: 250000 scale. British Geological Survey, Keyworth, for Palestinian Water Authority, Ramallah.

Rofe \& Raffety (1965) West Bank hydrology 1963-1965: Analysis. Report Central Water Authority, Amman, Hashemite Kingdom of Jordan 
Sanford W (2002) Recharge and groundwater models: an overview. Hydrogeology Journal 10 (1): 110-120

Scanlon B R, Tyler S W, Wierenga P J (1997) Hydrologic issues in arid, unsaturated systems and implications for contaminant transport. Reviews of Geophysics, 35 (4): $461-490$

Simmers I, Hendickx J M H, Kruseman G P, Rushton K R (1997) Recharge of phreatic aquifers in (semi-) arid areas. International Association of Hydrogeologists, International Contributions to Hydrogeology 19

Spink AEF, Jackson CR, Hughes AG and Hulme PJ 2003. The Benefits of ObjectOriented Modeling Demonstrated through the Development of a Regional Groundwater Model. .MODFLOW and More 2003: Understanding through Modeling - Conference Proceedings, Poeter, Zheng, Hill and Doherty. pp 336-340.

Spink, AEF, Hughes AG, Jackson CR, and Mansour MM, 2006. Object-oriented Design in Groundwater Modelling. MODFLOW and More 2006: Managing GroundWater Systems - Conference Proceedings, Poeter, Hill and Zheng. Colorado School of Mines, USA.

Stuart ME, Gooddy DC, G. Hughes AG and Jackson CR (2006) A Field And Modelling Study To Determine Pesticide Occurrence In A Public Water Supply In Northern England, UK. Ground Water Monitoring Remediation Vol. 26 pt/no 4 
De Vries J J Simmers I (2002) Groundwater recharge: an overview of processes and challenges. Hydrogeology Journal 10 (1): 5-17

Wood W W, Rainwater K A, Thompson D B (1997) Quantifying macropore recharge: examples from a semi-arid area. Ground Water 35 (6): 1097-1106 
Recharge to an upland karst aquifer in a semi-arid environment - Version 3 (7/12/07)

TABLE 1 Recharge reported as percentage of the long term average (LTA) from a variety of arid and semi-arid karst aquifers

\begin{tabular}{|l|l|l|l|l|}
\hline Location & LTA & Recharge & Comments & Source \\
& Rainfall & $(\%)$ & & \\
\hline Saudi Arabia & 70 & 47 & & \\
\hline Saudi Arabia & 198 & 47 & via sinkholes & De Vries \& Simmers (2002) \\
\hline Portuguese Algarve & 550 & $27-55$ & & De Vries \& Simmers (2002) \\
\hline Niger (Sahel) & $500-600$ & 10 & via matrix & Leduc et al. (1997) \\
\hline
\end{tabular}


TABLE 2 Previous recharge estimates $\left(\mathrm{Mm}^{3} \mathrm{a}^{-1}\right)$

\begin{tabular}{|c|c|c|c|c|c|}
\hline & Mean & Minimum & Source & Maximum & Source \\
\hline $\begin{array}{l}\text { Western Aquifer } \\
\text { Basin }\end{array}$ & 350 & 318 & $\begin{array}{l}\text { Goldschmidt \& } \\
\text { Jacobs (1958) }\end{array}$ & 366 & MNIWC (1999) \\
\hline $\begin{array}{l}\text { Eastern Aquifer } \\
\text { Basin }\end{array}$ & 130 & 119 & $\begin{array}{l}\text { Guttman \& } \\
\text { Zukerman (1995) }\end{array}$ & 197 & CDM (1998) \\
\hline $\begin{array}{l}\text { North-Eastern } \\
\text { Aquifer Basin* }\end{array}$ & 145 & - & & - & \\
\hline $\begin{array}{l}\text { Overall West } \\
\text { Bank }\end{array}$ & 825 & 800 & Guttman (1995) & 836 & $\begin{array}{l}\text { Rofe \& Raffety } \\
\text { (1965) }\end{array}$ \\
\hline
\end{tabular}

* Too few values to generate maximum and minimum values 
TABLE 3 C and D values ( $\mathrm{mm}$ ) for the soil moisture deficit method according to landuse

\begin{tabular}{|l|l|l|}
\hline Landuse & Root constant C & Wilting Point D \\
\hline Arrable, including & Monthly values used ranging & Monthly values used ranging \\
permanent crops & from $30 \mathrm{~mm}$ in Dec to 83 & from $34 \mathrm{~mm}$ in Nov and Dec to \\
\hline Urban & 50 & $132 \mathrm{~mm}$ in May \\
\hline Dead Sea & 1000 & 80 \\
\hline Rough grazing & 76 & 1000 \\
\hline Woodland & 203 & 127 \\
\hline Undefined & 50 & 254 \\
\hline
\end{tabular}


Recharge to an upland karst aquifer in a semi-arid environment - Version $3(7 / 12 / 07)$

TABLE 4 Long term average recharge volumes for the whole of the West Bank derived from the model (area $6450 \mathrm{~km}^{2}$ ) for the nine runs. Where urban and irrigation losses are included in the recharge calculation, these are shown as 'on'.

\begin{tabular}{|l|l|l|l|l|l|l|l|l|}
\hline & WT & WT & WT & WT & WT & SMD & SMD & SMD \\
\hline Urban & $30 \mathrm{~mm}$ & $30 \mathrm{~mm}$ & $30 \mathrm{~mm}$ & $40 \mathrm{~mm}$ & & & \\
\hline Irrigation & & & & ON & & & & ON \\
\hline $\begin{array}{l}\text { Recharge, } \\
\text { Mm }^{3} \mathrm{a}^{-1}\end{array}$ & 1002 & 911 & 931 & 967 & 851 & 611 & 637 & 677 \\
\hline $\begin{array}{l}\text { Recharge, } \\
\text { Mm a }^{-1}\end{array}$ & 155 & 141 & 144 & 150 & 132 & 95 & 99 & 105 \\
\hline
\end{tabular}


TABLE 5 Recharge values calculated for each basin (units in both $\mathrm{Mm}^{3} \mathrm{a}^{-1}$ and $\mathrm{mm} \mathrm{a}^{-1}$ ).

\begin{tabular}{|c|c|c|c|c|c|c|}
\hline 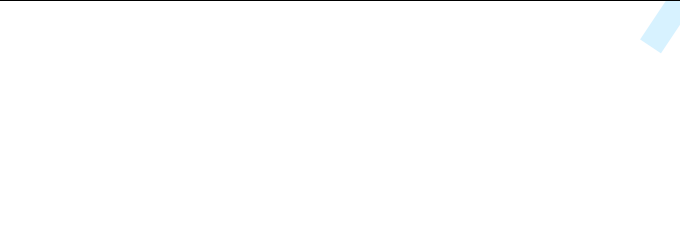 & $\begin{array}{l}\text { WT } \\
20 \mathrm{~mm}\end{array}$ & $\begin{array}{l}\text { WT } \\
30 \mathrm{~mm}\end{array}$ & $\begin{array}{l}\text { WT } \\
30 \mathrm{~mm}+\text { urban } \\
+ \text { irrigation }\end{array}$ & $\begin{array}{l}\text { WT } \\
40 \mathrm{~mm}\end{array}$ & SMD & $\begin{array}{l}\text { SMD + urban }+ \\
\text { irrigation }\end{array}$ \\
\hline Western Aquifer Basin $\left(\mathrm{Mm}^{3} \mathrm{a}^{-1}\right)$ & 455 & 415 & 430 & 387 & 269 & 287 \\
\hline Western Aquifer Basin $\left(\mathrm{mm} \mathrm{a}^{-1}\right)$ & 200 & 182 & 189 & 170 & 118 & 126 \\
\hline Eastern Aquifer Basin $\left(\mathrm{Mm}^{3} \mathrm{a}^{-1}\right)$ & 320 & 288 & 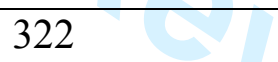 & 267 & 195 & 236 \\
\hline Eastern Aquifer Basin $\left(\mathrm{mm} \mathrm{a}^{-1}\right)$ & 109 & 98 & 109 & 91 & 66 & 80 \\
\hline North-eastern Aquifer Basin $\left(\mathrm{Mm}^{3} \mathrm{a}^{-1}\right)$ & 227 & 208 & 214 & 196 & 147 & 154 \\
\hline North-eastern Aquifer Basin $\left(\mathrm{mm} \mathrm{a}^{-1}\right)$ & 184 & 170 & 174 & 160 & 120 & 125 \\
\hline
\end{tabular}


TABLE 6 Application of the ZOODRM distributed recharge model to date showing the objects used within each model

\begin{tabular}{|c|c|c|c|c|c|c|c|c|}
\hline Location & Aquifer Type & $\sum_{\sim}$ & 5 & 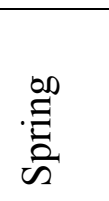 & $\begin{array}{l}\stackrel{\Psi}{\rightleftarrows} \\
\stackrel{\Xi}{\Xi} \\
\stackrel{\Xi}{\approx}\end{array}$ & 哇兽 & 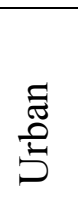 & 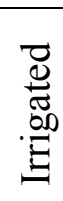 \\
\hline Wadi Natuf, West Bank & Upland Limestone & $\bar{X}$ & $\mathrm{X}$ & $\mathrm{X}$ & $\mathrm{X}$ & $\bar{X}$ & & \\
\hline West Bank & Upland Limestone & $X$ & $X$ & & $\mathrm{X}$ & $X$ & $X$ & $X$ \\
\hline Swanscombe UK & Cretaceous Chalk & $\bar{X}$ & - & & & $\bar{X}$ & $\mathrm{X}$ & \\
\hline Brighton UK & Cretaceous Chalk & $\mathrm{X}$ & & & $\mathrm{X}$ & & $\mathrm{X}$ & \\
\hline Gatehampton UK & Alluvium and Chalk & $\mathrm{X}$ & & $\bar{P}$ & $\mathrm{X}$ & $\bar{X}$ & & \\
\hline Vowchurch UK & Alluvium over sandstone & $\mathrm{X}$ & & & $\mathrm{X}$ & $\mathrm{X}$ & 8 & \\
\hline South Kennet UK & Various & $X$ & & & & $X$ & C & \\
\hline China & & & $\mathrm{X}$ & & $\mathrm{X}$ & $\mathrm{X}$ & & \\
\hline Ullapool UK & Alluvium & $\mathrm{X}$ & & & $\mathrm{X}$ & $\mathrm{X}$ & & \\
\hline Howden UK & Alluvium & $\mathrm{X}$ & & & $\mathrm{X}$ & $\mathrm{X}$ & & \\
\hline
\end{tabular}




\section{LIST OF FIGURES}

Fig 1. The political boundary of the West Bank with groundwater and topographic divides.

Fig 2. Framework of the recharge model

Fig 3. The calculation procedure for the distributed recharge model ZOODRM.

Fig 4. Spatial LTA recharge output from the model. Results produced using (a) the wetting threshold (WT) method with WT $=30 \mathrm{~mm}$, (b) the soil moisture deficit (SMD) method, and (c) a composite soil moisture deficit and wetting threshold model

Fig 5. Observed and modelled flow rates for Wadi Soreq 


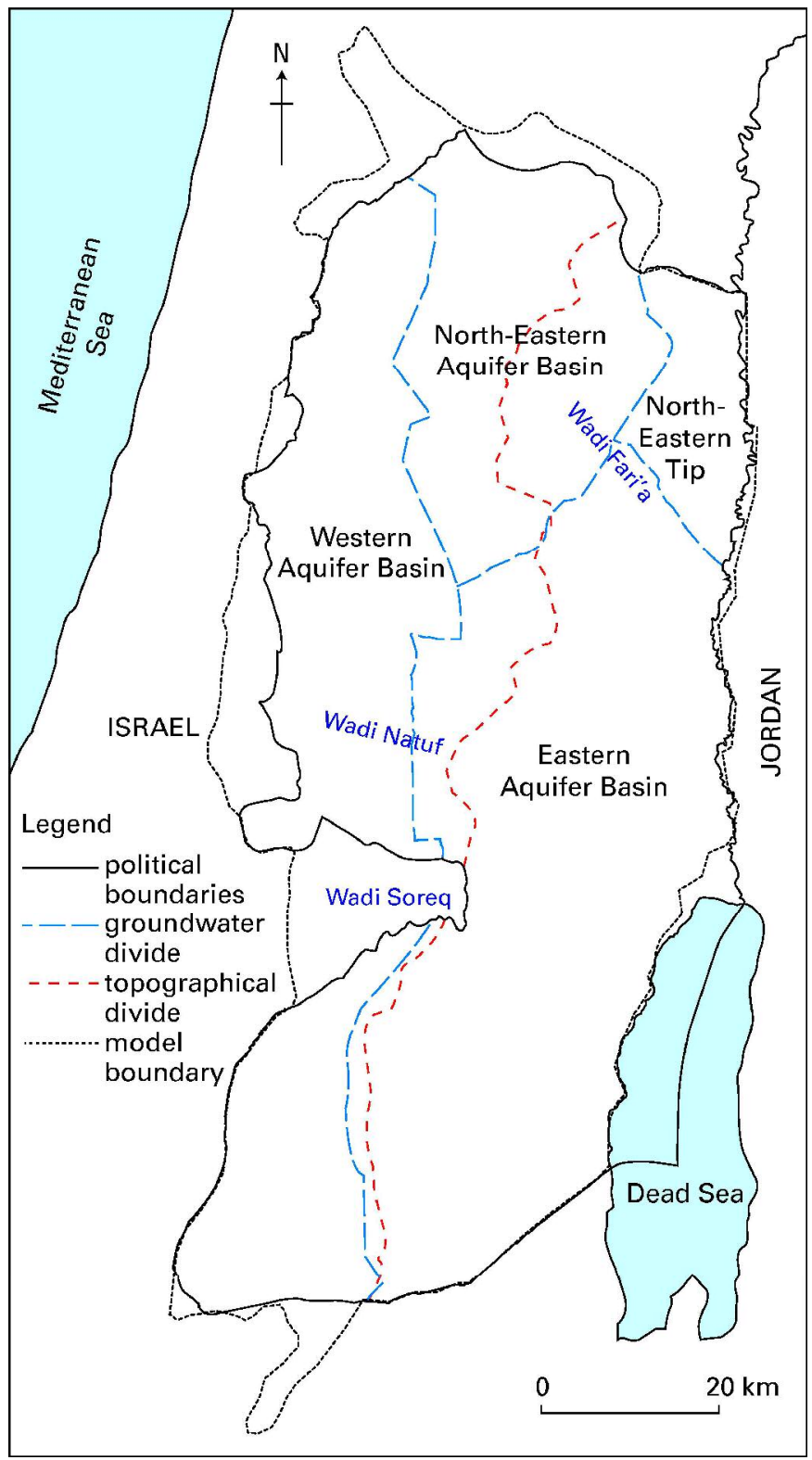

The political boundary of the West Bank with groundwater and topographic divides. $85 \times 154 \mathrm{~mm}(600 \times 600 \mathrm{DPI})$ 


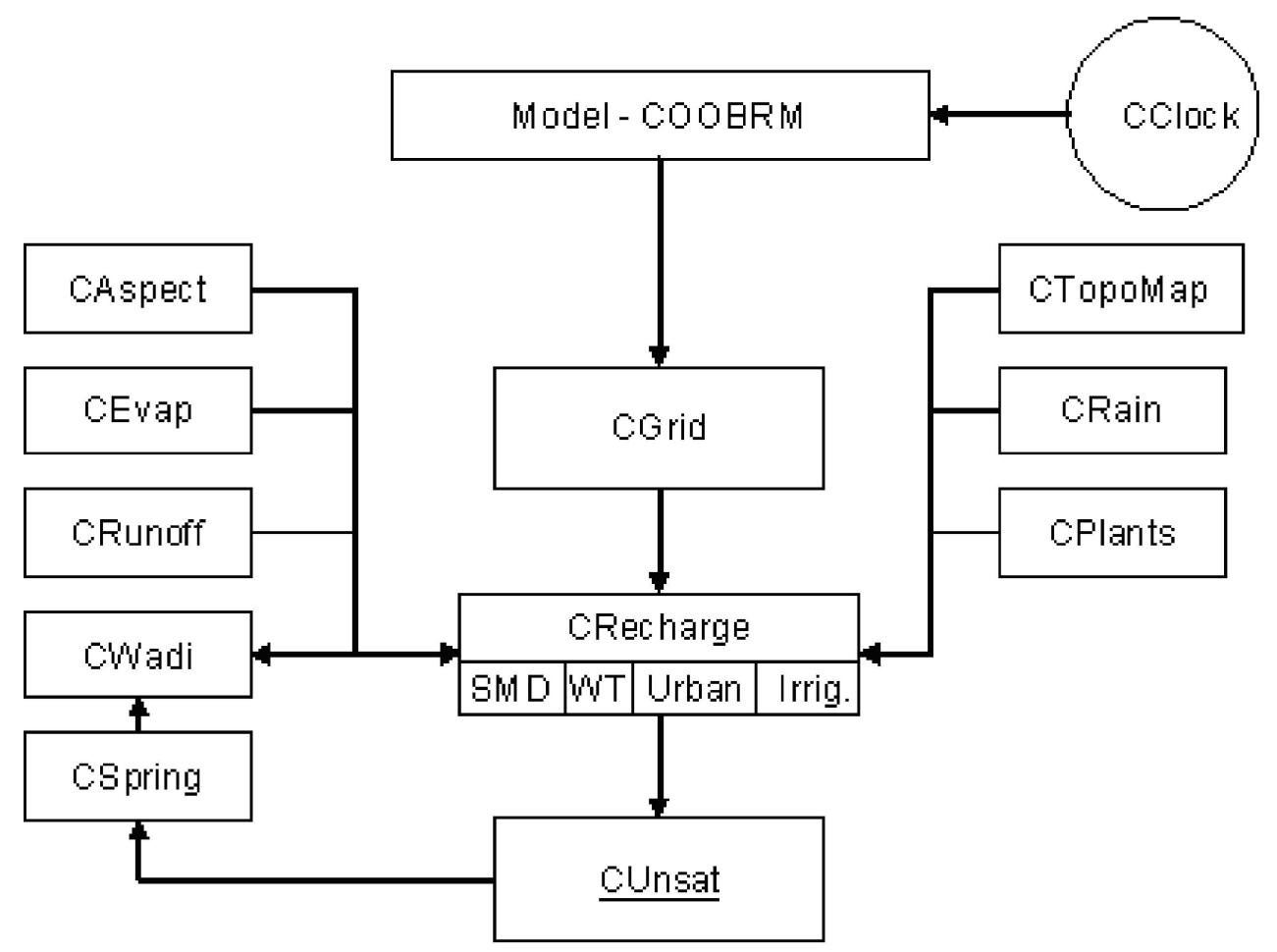

Framework of the recharge model.

$153 \times 111 \mathrm{~mm}(600 \times 600 \mathrm{DPI})$ 

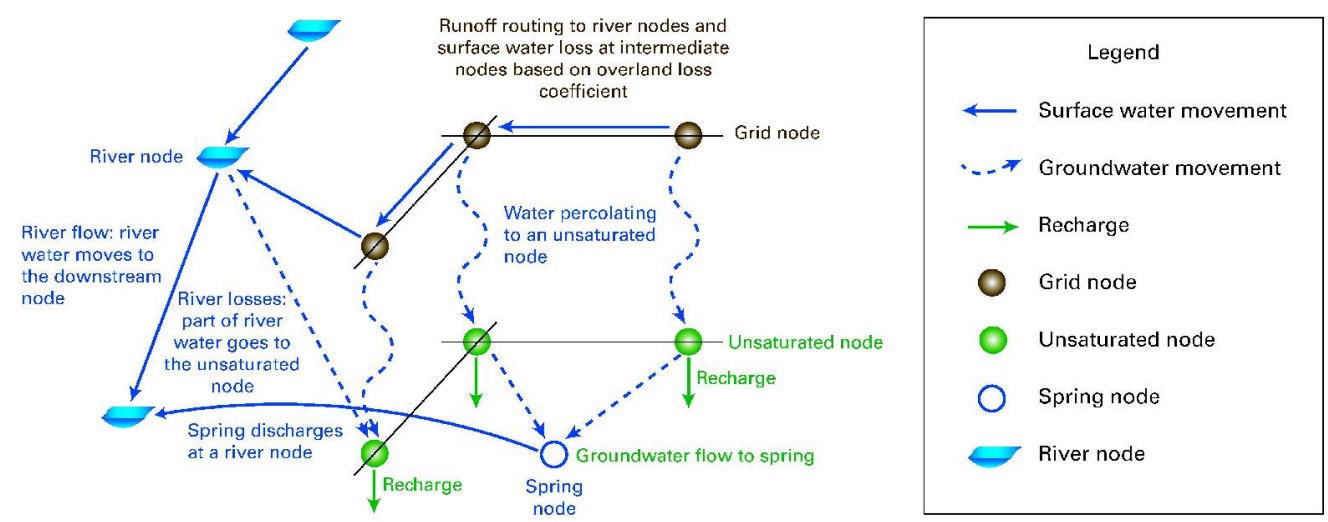

The calculation procedure for the distributed recharge model ZOODRM. $176 \times 68 \mathrm{~mm}(600 \times 600 \mathrm{DPI})$ 


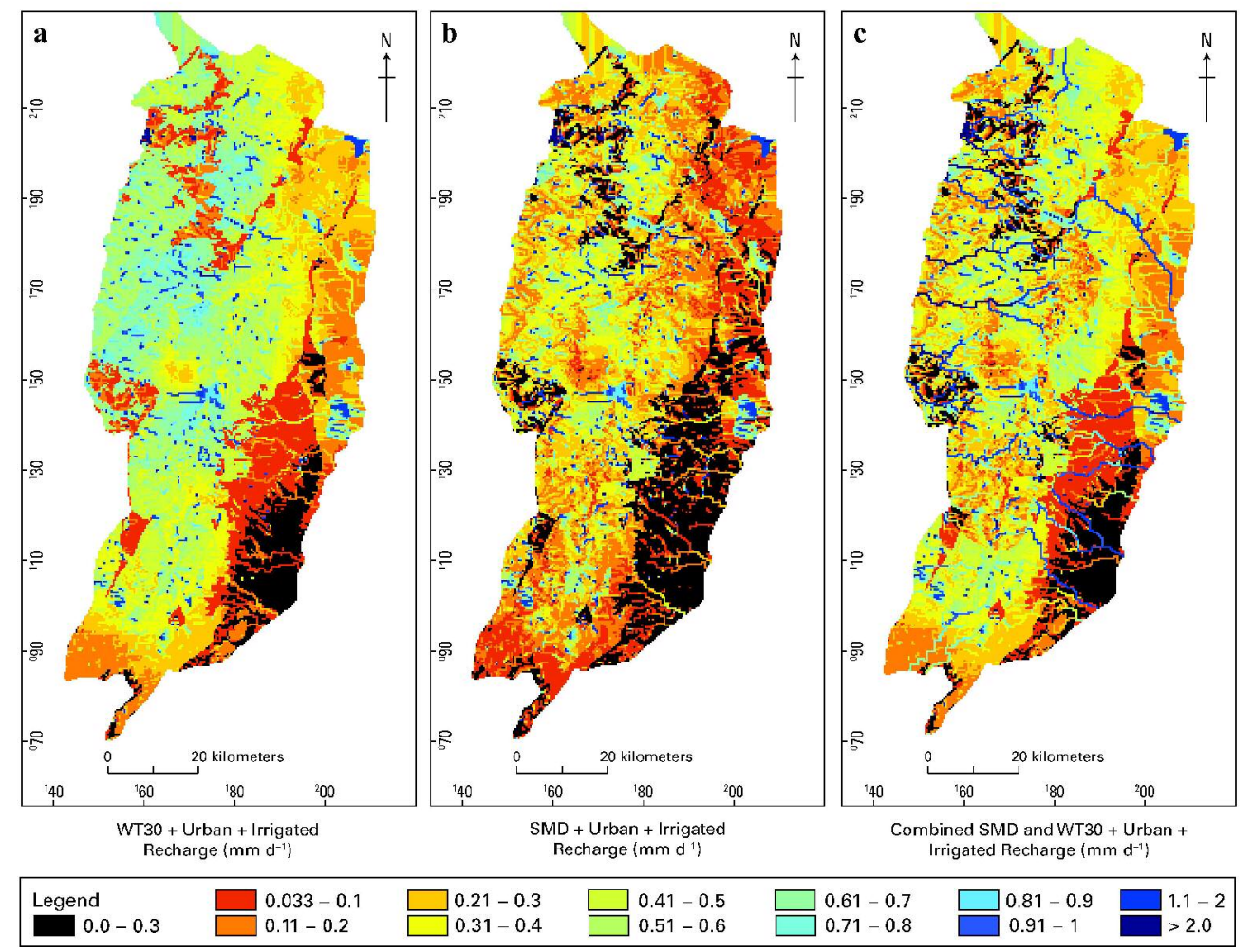

Spatial LTA recharge output from the model. Results produced using (a) the wetting threshold (WT) method with WT=30mm, (b) the soil moisture deficit (SMD) method, and (c) a composite soil moisture deficit and wetting threshold model. $179 \times 138 \mathrm{~mm}(600 \times 600 \mathrm{DPI})$ 


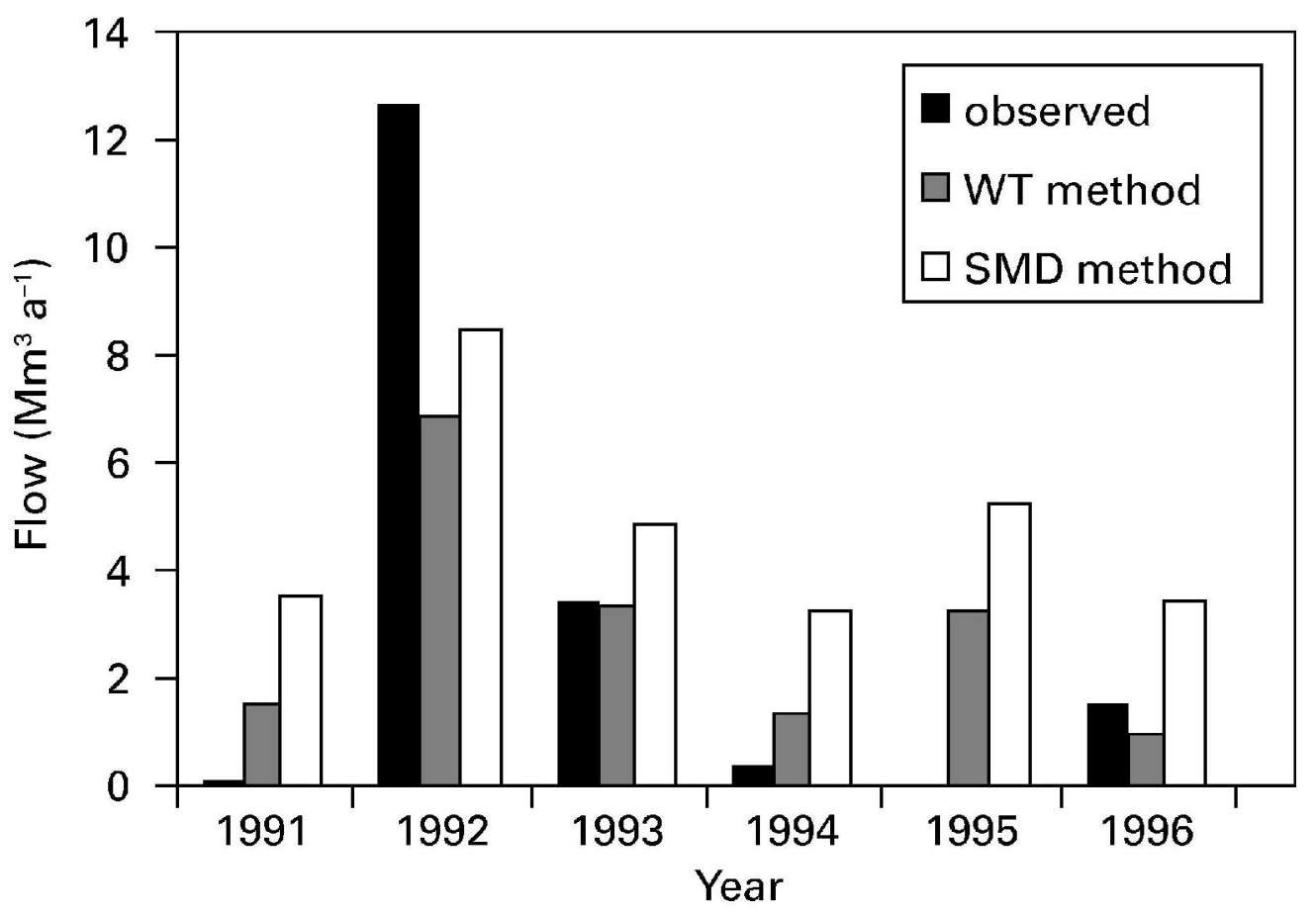

Observed and modelled flow rates for Wadi Soreq.

$84 \times 59 \mathrm{~mm}(600 \times 600$ DPI $)$ 
HJ-2007-0548

\section{Résumé}

Il est difficile d'évaluer la recharge d'un aquifère calcaire karstique qui présente une structure complexe et qui est localisé en montagne dans un environnement semi-aride. Le recours à des indicateurs, tels que la mesure du débit d'une source ou le rendement d'un puits, représente une alternative commune, et essayer d'effectuer conventionnellement une analyse du déficit d'humidité du sol risque de ne pas prendre en compte les conditions associées aux crues intermittentes, lesquelles sont propres à de tels environnements. A titre d'essai, une approche par modélisation a été effectuée sur le système aquifère de West Bank Mountain au Moyen-Orient. Le modèle utilise un logiciel orienté objet, ce qui permet d'activer ou de désactiver un groupe d'objets. Chacun des principaux processus de recharge identifiés sur le West Bank est incorporé. Le modèle permet soit de réaliser des calculs conventionnels de déficit d'humidité du sol, soit de faire des calculs de seuil d'humidification et il permet de prendre en compte à la fois la recharge directe et la recharge secondaire. Des pas de temps journaliers permettent de calculer en chaque noeud la trajectoire de la recharge et du ruissellement. Le modèle a permis d'effectuer des séries de simulations pour chacun des trois bassins aquifères du West Bank ainsi que pour la totalité du West Bank. Ce travail a fourni des estimations comparables à celles obtenues précédemment par des moyens conventionnels. Ce modèle est transposable et a été appliqué avec succès à d'autres environnements. 
HJ-2007-0548

\section{ABSTRACT}

La evaluación de recarga en un acuífero de caliza kárstica estructuralmente complejo de tierras altas es difícil. Una alternativa común consiste en recurrir a indicadores sustitutos tal como la medición de descargas de manantial y descarga de sondeos mientras que los intentos de aplicar los análisis convencionales de déficit de humedad de suelo pueden no explicar adecuadamente para las condiciones torrenciales intermitentes que se presentan en tales ambientes. Se ha utilizado un enfoque de modelizado usando el sistema Acuífero de la Montaña del Banco Occidental en el Medio Oriente como prueba. El modelo usa un programa orientado al objeto el cual permite que varios objetos se enciendan y apaguen. Se incorpora cada uno de los principales procesos de recarga identificados en el Banco Occidental. El modelo permite ya sea cálculos convencionales de análisis de déficit de humedad de suelo o cálculos de umbrales de humedad para ser hechos como apropiados, acomodando tanto la recarga directa como la recarga secundaria. Los intervalos de tiempo diario permiten calcular para cada nodo las rutas de escorrentía y recarga. Las corridas del modelo han permitido una serie de simulaciones para cada una de las tres cuencas de acuíferos en el Banco Occidental y para todo el Banco Occidental. Las simulaciones aportan estimados de recarga que son comparables a los elaborados por investigadores previos usando medios convencionales. El modelo es adaptable y se ha utilizado exitosamente en otros ambientes. 